\title{
Sulfide stress and tolerance in the lugworm Arenicola marina during low tide
}

\author{
Susanne Völkel, Kerstin Hauschild, Manfred K. Grieshaber
}

Institut für Zoologie, Lehrstuhl für Tierphysiologie, Heinrich-Heine-Universität, Universitätsstr. 1, D-40225 Düsseldorf, Germany

\begin{abstract}
In the present study environmental sulfide concentrations in the vicinity of and within burrows of the lugworm Arenicola marina during tidal exposure are presented. Sulfide concentrations in the pore water of the sediment ranged from 0.4 to $252 \mu \mathrm{M}$. During $4 \mathrm{~h}$ of tidal exposure no significant changes of pore water sulfide concentrations were observed. Up to $32 \mu \mathrm{M}$ sulfide were measured in the water of lugworm burrows. During $4 \mathrm{~h}$ of low tide the percentage of burrows containing sulfide increased from 20 to $50 \%$ in July and from 36 to $77 \%$ in October A significant increase of median sulfide concentrations from 0 to $14.5 \mu \mathrm{M}$ was observed after $5 \mathrm{~h}$ of emersion. Sulfide and thiosulfate concentrations in the coelomic fluid and succinate, alanopine and strombine levels in the body wall musculature of freshly caught $A$. marina were measured. During $4 \mathrm{~h}$ of tidal exposure in July the percentage of lugworms containing sulfide and maximal sulfide concentrations increased from $17 \%$ and $5.4 \mu \mathrm{M}$ to $62 \%$ and $150 \mu \mathrm{M}$, respectively. A significant increase of median sulfide concentrations was observed after 2 and $3 \mathrm{~h}$ of emersion. In October, changes of sulfide concentrations were less pronounced. Median thiosulfate concentrations were 18 to $32 \mu \mathrm{M}$ in July and 7 to $12 \mu \mathrm{M}$ in October No significant changes were observed during tidal exposure. Succinate accumulated in the tissue of A. marina, indicating the onset of an environmental and sulfide dependent anaerobiosis. Recovery experiments after $4 \mathrm{~h}$ of tidal exposure showed that sulfide is completely removed from the coelomic fluid after $30 \mathrm{~min}$. Succinate levels began to decrease immediately after the disappearance of sulfide, reaching control levels after 60 min of recovery. Thiosulfate concentration showed a significant increase after $30 \mathrm{~min}$, indicating that internal sulfide is removed by its oxidation to thiosulfate. The present study shows that $A$. marina exhibits the same mechanisms of sulfide tolerance under habitat conditions as under experimental conditions. In addition, it is demonstrated that the lugworm is able to recover from tidal sulfide stress within $1 \mathrm{~h}$.
\end{abstract}

KEY WORDS: Arenicola marina S Sulfide tolerance - Tidal exposure - Sediment - Recovery

\section{INTRODUCTION}

Animals inhabiting the sediment of the intertidal zone can be exposed to pronounced fluctuations of abiotic conditions. The tidal rise and fall of the sea causes periodical changes in temperature, salinity and oxygen supply. The lugworm Arenicola marina lives about 10 to $30 \mathrm{~cm}$ deep in the sediment of intertidal flats. During high tide its U-shaped burrow is irrigated by peristaltic movements of its body wall thus providing the animal with oxygen (Krüger 1971). At low tide when the burrow is emersed, ventilation becomes impossible and the lugworm is exposed to increasing hypoxia. Jones (1955) demonstrated that the $\mathrm{P}_{\mathrm{O}_{2}}$ in the remaining water of the lugworm burrow decreases from about 33 to 13 torr during 2 h of tidal emersion. Correspondingly, blood oxygen content drops nearly to zero within the first hour of tidal emersion (Toulmond 1973). In the hypoxic period $A$. marina reduces its ventilatory movements and oxygen consumption and switches from aerobic to anaerobic metabolism (Schöttler et al. 1984a, Toulmond \& Tchernigovtzeff 1984, Toulmond 1987, Grieshaber et al. 1992). Thus, the accumulation of typical anaerobic metabolites such as succinate, acetate and propionate in the body wall tissue and blood of $A$. marina was observed during tidal exposure (Pionetti \& Toulmond 1980, Schöttler et al. 1984 b). When the tide comes back in, the burrow is ventilated again and the lugworm can return to an aerobic metabolism. Pörtner et al. (1979) showed that 
A. marina recovered from anoxia with most of the tissue metabolites reach control levels during 1 to $2 \mathrm{~h}$ of normoxic incubation.

Apart from irrigated burrows of the tubebuilding infauna, oxygen is not measurable in the pore water of the deeper layers of the marine sediment (Brafield 1964, Watling 1991). These reduced layers are commonly characterized by the presence of sulfide, which is mainly produced by sulfate-reducing bacteria (Jørgensen \& Fenchel 1974, Kröger et al. 1988). Sulfide concentrations in the sediment pore water of marine habitats can range from a few $\mu \mathrm{M}$ up to several $\mathrm{mM}$ (see Bagarinao 1992) depending on the structure of the sediment and organic matter production (Fenchel \& Riedl 1970). The rate of sulfate reduction shows seasonal fluctuations which are mainly caused by changes of temperature and organic matter supply (Nedwell \& Floodgate 1972, Jørgensen 1977). Sulfide concentrations in sediment pore water are usually high in summer and low during the cold months (Jørgensen 1977, Völkel \& Grieshaber 1992). Diel fluctuations of sulfide can occur as a consequence of changing light conditions (De Wit et al. 1989).

In the vicinity of lugworm burrows sulfide concentrations up to $340 \mu \mathrm{M}$ have been observed (Groenendaal 1979, Völkel \& Grieshaber 1992). Sulfide is assumed to diffuse from the pore water along the chemical gradient into the lugworm burrow (Aller 1980. Waslenchuk et al. 1983). During high tide sulfide may be delivered to the overlying water as the lugworm irrigates its burrow. Sulfide is, moreover, likely to be oxidized rapidly by the oxygen-rich seawater (Cline \& Richards 1969, Millero 1986). Sulfide will therefore only be rarely found in burrows which are covered by tide. During tidal exposure, however, the burrow water is stagnant and becomes hypoxic isee above). Sulfide diffusing into the burrow cannot be flushed out or oxidized and Arenicola marina may be exposed to increasing sulfide concentrations as long as the burrow is emersed. Arp et al. (1992), for example, measured sulfide concentrations up to $66 \mu \mathrm{M}$ in the burrow water of Urechis caupo after $2 \mathrm{~h}$ of tidal exposure. As soon as the tide comes back in, the worm is able to ventilate again and sulfide will be removed from the burrow. A. marina is thus exposed not only to a repetitive lack of oxygen but also to periodically changing sulfide concentrations during tidal cycles.

Sulfide is a strong inhibitor of the cytochrome c oxidase (National Research Council 1979). Despite sulfide's toxicity, numerous organisms possess several mechanisms of sulfide tolerance and can live in sulfide-rich habitats (for reviews see Vetter et al. 1991, Vismann 1991). Arenicola marina is highly insensitive to sulfide (Groenendaal 1980). Its sulfide tolerance has been investigated in the laboratory and is based upon
3 main strategies: (1) in the presence of oxygen, sulfide entering the body is rapidly oxidized to thiosulfate which accumulates in the coelomic fluid of $A$. marina. The oxidation of sulfide could be localized in the mitochondria of its body wall tissue (Völkel \& Grieshaber 1992, 1994). (2) During hypoxia, the sulfide concentration in the body of $A$. marina is reduced by the acidification of the coelomic fluid (Groenendaal 1981, Völkel \& Grieshaber 1992). (3) The increase of sulfide in the body can be tolerated by switching to an anaerobic metabolism as indicated by the accumulation of anaerobic metabolites (Völkel \& Grieshaber 1992, 1994, see also Grieshaber et al. 1992). Although these mechanisms have been demonstrated under extreme experimental conditions, up to now it is not known whether they also play a role in the lugworm's habitat. The aim of this study, therefore, was (1) to determine the environmental sulfide concentrations to which A. marina is exposed during prolonged low tide, (2) to investigate whether A. marina exhibits the same mechanisms of sulfide tolerance in its natural habitat as under experimental conditions, and (3) to investigate the time course of recovery of $A$. marina from sulfide exposure during tidal emersion when reimmersed.

\section{MATERIAL AND METHODS}

Study site and sampling conditions. The studies took place at a mudflat located at the harbor of St. Pol de Léon, Brittany, France (English Channel). The site is characterized by a high population density of Arenicola marina. Sampling was performed during July 1991, July and October 1992 and October 1993 and 1994 when tidal heights were 0.9 to $1.5 \mathrm{~m}$ and peaks of low tide were around noon. All environmental and animal data were obtained within an area of about $10 \times 10 \mathrm{~m}$ which was exposed for 4 to $5 \mathrm{~h}$ during low tide. Sampling started as soon as the water had receded $(t=0)$ and was repeated after 1, 2, 3 and $4 \mathrm{~h}$ of emersion. During collecting trips air temperatures ranged from 12.5 to $24.9^{\circ} \mathrm{C}$ in July and 4.8 to $12.4^{\circ} \mathrm{C}$ in October (minimal and maximal temperatures, respectively; data obtained from the Station metéorologique, Brest, France). The weather was dry during all collecting trips with the exception of 15 July 1991 and 28 October 1992 when it started to rain after $1 \mathrm{~h}$ and $3 \mathrm{~h}$, respectively.

Sulfide concentration of the pore water. Sulfideconcentration of the pore water of the sediment was determined during 3 collecting trips in July 1991. Each time pore water was sampled from 2 different sites at a depth of 10,20 and $30 \mathrm{~cm}$. Pore water samplers as described by Völkel \& Grieshaber (1992) were inserted into the sediment immediately after emersion of the 
area and remained there for $4 \mathrm{~h}$. Every hour, 0.5 to $1 \mathrm{ml}$ pore water was collected, 3 samples from each depth and site. The samples were fixed in zinc acetate and $\mathrm{NaOH}$ and analyzed for sulfide within. 1 wk with the methylene blue method (Gilboa-Garber 1971) as described by Völkel \& Grieshaber (1992).

Sulfide concentration of the burrow water. The sulfide concentration of the burrow water was determined in July 1992 and in October 1992, 1993 and 1994. Burrow water was sampled using a polyethylene tube (length $30 \mathrm{~cm}$, inner diameter $1 \mathrm{~mm}$ ) which was attached to a $1 \mathrm{ml}$ tuberculin syringe. After the removal of the lugworm's cast the tube was carefully inserted into the burrow until it was hindered by the worm. Samples of 0.5 to $1 \mathrm{ml}$ were taken from each burrow. At each time point, 2 to 3 burrows were analyzed at the same time. The first sample was taken immediately after the emersion of the burrows and additional samples were taken hourly for $4 \mathrm{~h}$. In October 1993 the period of emersion was long enough to obtain samples after $5 \mathrm{~h}$ of emersion during 1 collecting trip. Each burrow was used only once to prevent artifacts arising from diffusion from the environment. Water samples were fixed and analyzed for sulfide as described above.

Determination of sulfur compounds and anaerobic end products in freshly caught Arenicola marina. Specimens of Arenicola marina were collected in July 1991, July and October 1992 and in October 1993. During each collecting trip, 2 to 3 lugworms $\mathrm{h}^{-1}$ were collected from unanalyzed burrows during the $4 \mathrm{~h}$ of emersion. The freshly caught lugworms were quickly washed in seawater. Coelomic fluid was collected by dorsally cutting the body wall. After that, the worms were dissected and the body wall tissue was freezeclamped (Wollenberger et al. 1960) and stored in liquid nitrogen.

For determination of sulfide and thiosulfate the coelomic fluid was immediately mixed with monobromobimane $\left(3 \mathrm{mmol} \mathrm{l}^{-1}\right.$ final concentration; Calbiochem, Giessen, Germany) and HEPES/EDTA (50/5 mmol $1^{-1}, \mathrm{pH} 8.0$ ) according to a modified method described by Vetter et al. (1989). As a control, parallel samples were prepared using 2-pyridyl disulfide (Vetter et al. 1989). After a reaction time of $30 \mathrm{~min}$ methansulfonic acid $\left(25 \mathrm{mmol} \mathrm{l}^{-1}\right.$ ) was added and the samples were frozen and stored in liquid nitrogen for 2 mo at most. In the laboratory, the samples were thawed and spun for $10 \mathrm{~min}$ (14550×g , Biofuge A, Heraeus Christ, Osterode, Germany). The supernatant was immediately analyzed for sulfur compounds by high-performance liquid chromatography (HPLC) as described by Völkel \& Grieshaber (1994)

For determination of succinate, alanopine and strombine the tissue was extracted according to Beis \&
Newsholm (1975). Succinate was measured spectrophotometrically as described by Beutler (1985). Alanopine and strombine were determined by HPLC using a DX-100 Ion Chromatograph (DIONEX, Idstein, Germany) for pumping and conductivity detection. The opines were isocratically separated at $45^{\circ} \mathrm{C}$ with a Polyspher ${ }^{\mathrm{R}} \mathrm{AR}$ AC cation exchange column (100-6.5, Merck, Darmstadt, Germany) using $7.5 \times 10^{-5} \mathrm{~N} \mathrm{H}_{2} \mathrm{SO}_{4}$ as a solvent $\left(0.6 \mathrm{ml} \mathrm{min}^{-1}\right)$.

Recovery experiments. During 2 collecting trips in Octaber 1993, 12 specimens of Arenicola marina were collected after $4 \mathrm{~h}$ of emersion. The lugworms were immediately placed into $10 \mathrm{l}$ aerated seawater from their habitat and were allowed to recover in darkness. After 15, 30,60 and $120 \mathrm{~min}$, respectively, 3 worms were removed from the tank. Coelomic fluid was collected and prepared for analysis of sulfur compounds and the body wall musculature was stored for determination of anaerobic end products as described above.

Data treatment. Results are reported as single data and medians respectively. Since most of the data were not normally distributed, significance of differences between medians were evaluated using the nonparametric Mann-Whitney $U$-test (2-tailed test) at the $p=0.05$ level (Beyer 1988).

\section{RESULTS}

\section{Sulfide in the pore water of the sediment}

Sulfide concentrations in the pore water ranged from 0.4 to $252.2 \mu \mathrm{M}$ (Fig. 1). Variations were high both between different sampling sites and between different sampling days. For instance, at a depth of $10 \mathrm{~cm}$ and at $t=0 \mathrm{~h}$, sulfide concentrations from 13.7 to $177.2 \mu \mathrm{M}$ could be measured. For the first 2 collecting trips (a, 12 July; b, 13 July 1991) sulfide concentrations in the pore water tended to increase during low tide. For the third collecting trip (c, 15 July 1991) sulfide concentrations increased in the first hour of emersion but decreased during the remaining $3 \mathrm{~h}$ of emersion. In almost all cases sulfide concentrations decreased with depth, e.g. from $77.8 \mu \mathrm{M}$ (a, site $\mathrm{I}, t=4 \mathrm{~h}$ ) at a depth of $10 \mathrm{~cm}$ to $7.8 \mu \mathrm{M}$ at $30 \mathrm{~cm}$. Due to the high variability of the data changes in sulfide concentrations during low tide were not significant.

\section{Sulfide in the burrow water}

Sulfide was present in $23 \%$ of the lugworm burrows analyzed during low tide in July $1992(\mathrm{n}=26)$ with concentrations ranging from 0.2 to $32 \mu \mathrm{M}$ (Fig. 2). Immedi- 

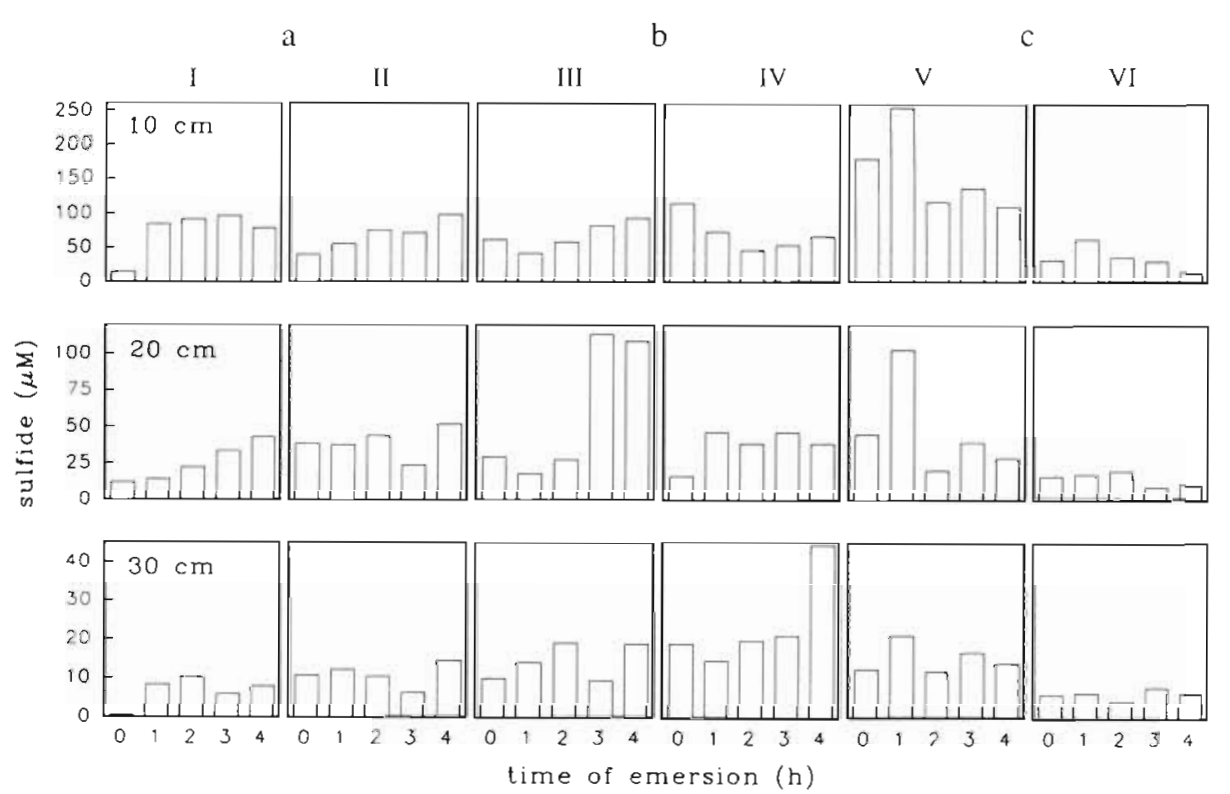

Fig. 1. Sulfide $(\mu M)$ in the pore water of the sediment in St. Pol de Léon (France). Samples were taken during tidal emersion at a depth of 10,20 and $30 \mathrm{~cm}$ at 6 different sites (I to $\mathrm{VI}$ ) and on 3 days $(a, b, c$ are 12,13 and 15 July 1991, respectively

ately after emersion and during the first $3 \mathrm{~h}$ of low tide sulfide was found in 1 of 5 burrows at most. In the same period of time median sulfide concentrations were $0 \mu \mathrm{M}$. After $4 \mathrm{~h}$ of emersion 3 of 6 burrows contained sulfide and the median concentration increased slightly, but not significantly, to $1.5 \mu \mathrm{M}$. In October 1992, 1993 and 1994 sulfide could be found in $50 \%$ of all lugworm burrows analyzed during low tide $(n=68)$. Sulfide concentrations ranged from 0.5 to $20 \mu \mathrm{M}$ (Fig. 2). Median

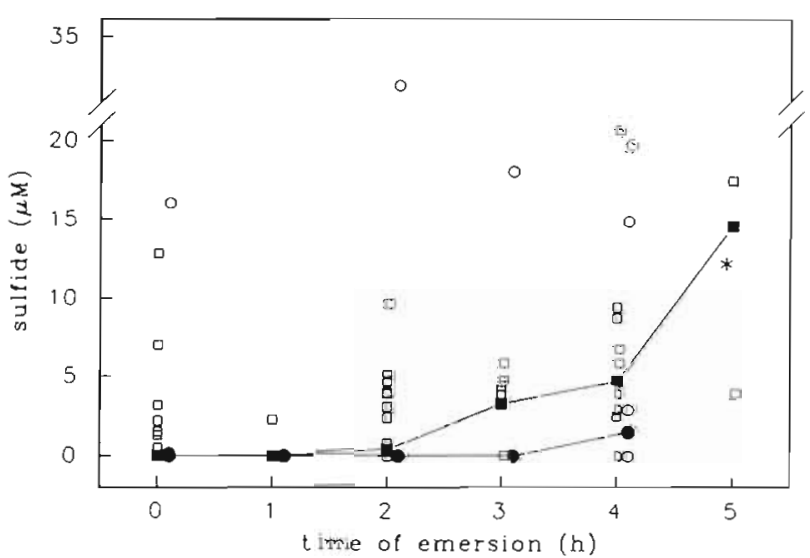

Fig. 2. Sulfide ( $\mu M()$ in the water of Arenicola marina burrows during tidal emersion. Data obtained in $(0, \bullet)$ July 1992 and $(\square, \square)$ October 1992, 1993 and 1994. Open symbols represent sulfide concentrations of single burrows; closed symbols are the respective medians. (*) Significant difference to the corresponding median at $t=0 \mathrm{~h}$. The number of analyzed burrows at $t=0,1,2,3,4$ and $5 \mathrm{~h}$ was (with the respective number of burrows containing no sulfide in parentheses): $5(4), 5(5), 5(4), 5(4), 6(3)$ and $0(0)$ in July and $14(9), 13(12)$, $16(8), 9(4), 13(3)$ and $3(0)$ in October. For clarity, July data are shifted to the right sulfide concentrations were $0 \mu \mathrm{M}$ during the first hour of emersion with 10 to $40 \%$ of the burrows containing sulfide. Median sulfide concentrations increased, although not significantly, to $4.7 \mu \mathrm{M}$ after $4 \mathrm{~h}$ of emersion, when sulfide could be measured in $77 \%$ of the burrows. After 5 h of emersion sulfide was found in all 3 burrows analyzed and median concentration rose significantly to $14.5 \mu \mathrm{M}$.

\section{Sulfur compounds in the coelomic fluid of Arenicola marina}

\section{Sulfide}

During collecting trips in July 1991 and 1992 sulfide was measured in the coelomic fluid of $46 \%$ of 37 freshly caught specimens of Arenicola marina, with concentrations ranging from 5.4 to $150 \mu \mathrm{M}$ (Fig. 3A). During tidal exposure, the percentage of lugworms containing sulfide, the medians of the sulfide concentrations and the maximal sulfide concentrations increased from $17 \%, 0 \mu \mathrm{M}$ and $5.4 \mu \mathrm{M}$ at the beginning to $62 \%, 35.1 \mu \mathrm{M}$ and $150.0 \mu \mathrm{M}$, respectively, after $4 \mathrm{~h}$ of emersion. Due to the high variations between lugworms the increase of sulfide concentration of the coelomic fluid was only significant after 2 and $3 \mathrm{~h}$ but not after $4 \mathrm{~h}$ of emersion when compared to $t=0 \mathrm{~h}$ (Fig. 3A). In October 1992 and 1993, 49 specimens of A. marina were analyzed, $57 \%$ of which contained sulfide ranging from 0.7 to $13 \mu \mathrm{M}$ (Fig. 3A). As in July, the percentage of lugworms containing sulfide, the median and the maximal sulfide concentrations increased with duration of low tide $33 \%, 0 \mu \mathrm{M}$ and 

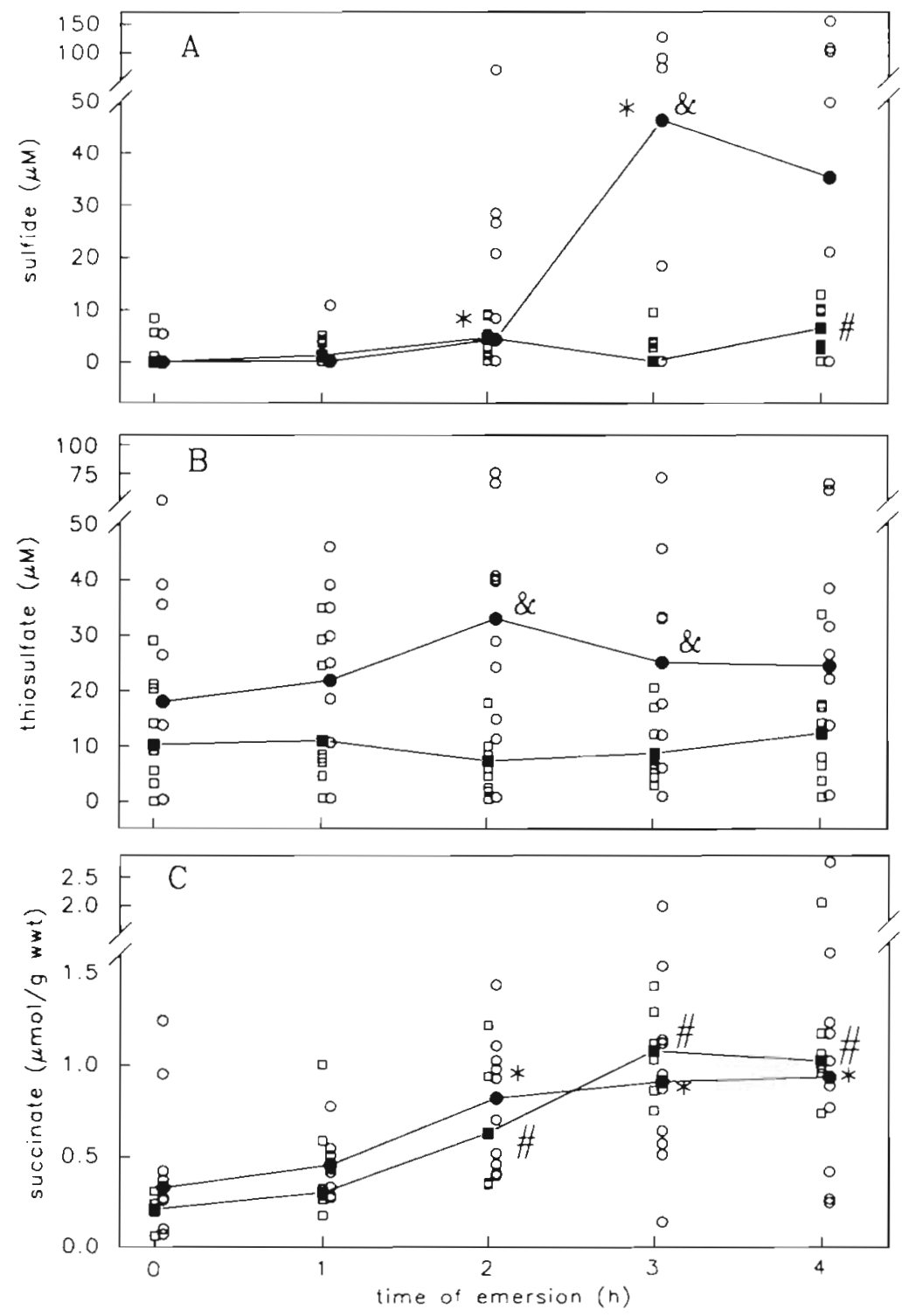

Fig. 3. Arenicola marina. (A) Sulfide $(\mu \mathrm{M})$ and $(B)$ thiosulfate $(\mu \mathrm{M})$, both in the coelomic fluid, and (C) succinate ( $\mu \mathrm{mol} \mathrm{g}^{-1}$ wet $\mathrm{wt}$ ) in the body wall tissue of freshly caught lugworms during tidal emersion. Data obtained in $(0, \bullet)$ July 1991 and 1992 and $(\square, \square)$ October 1992 and 1993. Open symbols represent data of individual lugworms; closed symbols are the respective medians. * \# indicate significant differences of the medians to the corresponding median at $t=0 \mathrm{~h}$ (*-July, \#: October). \&: significant difference between July and October values. For clarity, July data are shifted to the right. The number of lugworms analyzed for each component at $t=0,1,2,3$ and $4 \mathrm{~h}$ was (with the number of lugworms containing no sulfide, thiosulfate or succinate in parentheses): (A) sulfide: $6(5), 7(6), 9(4), 7(2)$ and $8(3)$ in July and $9(6), 9(3), 11(3), 11(7)$ and $9(2)$ in October; (B) thiosulfate: $9(3), 10(3), 11(2), 10(1)$ and $10(3)$ in July and $12(1), 12(0), 12(1), 12(0)$ and $10(1)$ in October; (C) succinate: $9(0), 11(0), 12(0)$. $10(0)$ and $11(0)$ in July and $5(0), 6(0), 6(0), 6(0)$ and $6(0)$ in October

$8.4 \mu \mathrm{M}$ at the beginning to $78 \%, 6.4 \mu \mathrm{M}$ and $12.8 \mu \mathrm{M}$, respectively, after $4 \mathrm{~h}$ of tidal exposure). A significant increase of median sulfide concentrations could only be measured after $4 \mathrm{~h}$ of emersion. Median sulfide con- centrations of October specimens after 3 and $4 \mathrm{~h}$ were much (significantly at $t=$ 3 h) lower than the corresponding July values $(0$ and $6.4 \mu \mathrm{M}$ as opposed to 46.0 and $35.1 \mu \mathrm{M}$ respectively; Fig. $3 \mathrm{~A}$ ). Likewise, maximal sulfide concentrations were only 9 to $13 \mu \mathrm{M}$ in lugworms collected in October as compared to 66 to $150 \mu \mathrm{M}$ in those collected in July after 2 to 4 h of emersion.

\section{Thiosulfate}

In July 1991 and 1992 thiosulfate could be measured in the coelomic fluid of $76 \%$ of the lugworms $(n=50)$. The concentrations ranged from 10.2 to $73.0 \mu \mathrm{M}$, median concentrations were 17.7 to $32.2 \mu \mathrm{M}$ (Fig. 3B). During $4 \mathrm{~h}$ of tidal emersion no significant changes of median or maximal thiosulfate concentrations or of the percentage of lugworms containing thiosulfate could be observed. In October 1992 and 1993, 58 specimens of Arenicola marina were analyzed, $95 \%$ of which contained thiosulfate at concentrations of 0.4 to $34.7 \mu \mathrm{M}$. As in July, no changes of median concentrations (6.9 to $11.6 \mu \mathrm{M}$ ), maximal concentrations or percentage of thiosulfate-containing lugworms were found. Medians were significantly lower in October than in July (at $t=$ 2 and $3 \mathrm{~h}$ ). Maximal thiosulfate concentrations in the coelomic fluid of lugworms collected in October were 1.5- to 4 -fold lower than of those collected in July (Fig. 3B)

\section{Anaerobic end products in the tissue of Arenicola marina}

The concentrations of succinate (July 1991 and 1992 and October 1992 and 1993), alanopine and strombine (July 1991 and 1992) in the body wall musculature of freshly caught Arenicola marina were determined in order to follow the onset of an anaerobic metabolism. In July median succinate concentrations increased significantly from $0.33 \mu \mathrm{mol} \mathrm{g}^{-1}$ wet wt at the beginning to $0.81 \mu \mathrm{mol} \mathrm{g} \mathrm{g}^{-1}$ wet wt after $2 \mathrm{~h}$ and $0.92 \mu \mathrm{mol} \mathrm{g}^{-1}$ wet wt after $4 \mathrm{~h}$ of emersion (Fig. 3C). 
The concentrations ranged from 0.07 to $1.24 \mu \mathrm{mol} \mathrm{g}^{-1}$ wet wt at $t=0 \mathrm{~h}$, from 0.39 to $1.43 \mu \mathrm{mol} \mathrm{g}^{-1}$ wet wt at $t=2 \mathrm{~h}$ and from 0.23 to $2.75 \mu \mathrm{mol} \mathrm{g}{ }^{-1}$ wet wt at $t=4 \mathrm{~h}$. Similarly, median and maximal succinate concentrations increased in the body wall tissue of lugworms collected in October with the length of tidal emersion (Fig. 3C). The median concentrations were $0.21 \mu \mathrm{mol}$ $\mathrm{g}^{-1}$ wet $\mathrm{wt}$ in the beginning and increased significantly to $0.62 \mu \mathrm{mol} \mathrm{g}{ }^{-1}$ wet wt after $2 \mathrm{~h}$ and to $1.01 \mu \mathrm{mol} \mathrm{g}{ }^{-1}$ wet wt after $4 \mathrm{~h}$ of emersion. The respective concentrations ranged from 0.06 to $0.31 \mu \mathrm{mol} \mathrm{g}^{-1}$ wet wt at $t=$ $0 \mathrm{~h}$, from 0.34 to $1.21 \mu \mathrm{mol} \mathrm{g}{ }^{-1}$ wet wt at $t=2 \mathrm{~h}$ and from 0.72 to $2.02 \mu \mathrm{mol} \mathrm{g}^{-1}$ wet wt at $t=4 \mathrm{~h}$. No significant differences were observed between lugworms collected in July and those collected in October.

Alanopine in the tissue remained constant (at a level of about $1 \mu \mathrm{mol} \mathrm{g} \mathrm{g}^{-1}$ wet wt) during $4 \mathrm{~h}$ of emersion although maximal alanopine concentrations tended to increase in the first $3 \mathrm{~h}$ of emersion (Table 1). The median strombine level increased significantly from $0.66 \mu \mathrm{mol} \mathrm{g}^{-1}$ wet wt at $t=0 \mathrm{~h}$ to $1.53 \mu \mathrm{mol} \mathrm{g}^{-1}$ wet wt after $3 \mathrm{~h}$ of emersion. Similarly, maximal strombine concentrations increased from 1.10 to $6.35 \mu \mathrm{mol} \mathrm{g} \mathrm{g}^{-1}$ wet $w$ t in the same period of time (Table 1). However, median and maximal strombines concentrations decreased to 0.88 and $3.95 \mu \mathrm{mol} \mathrm{g}^{-1}$ wet wt after $4 \mathrm{~h}$ of emersion.
Table 1 Arenicola marina. Alanopine and strombine ( $\mu$ mol $\mathrm{g}^{-1}$ wet $\left.w t\right)$ in the body wall tissue of freshly caught specimens during tidal emersion in July 1991 and 1992. n: number of analyzed lugworms. Maximal and minimal values and medians are given. 'Significant difference of the median of the 2 opines to the median at $t=0$

\begin{tabular}{|crccc|}
\hline $\begin{array}{c}\text { Time of emersion } \\
(\mathrm{h})\end{array}$ & $\mathrm{n}$ & $\begin{array}{c}\text { Min. } \\
\text { value }\end{array}$ & $\begin{array}{c}\text { Max. } \\
\text { value }\end{array}$ & Median \\
\hline Alanopine & & & & \\
0 & 8 & 0.49 & 1.40 & 0.86 \\
1 & 11 & 0.25 & 2.70 & 0.88 \\
2 & 12 & 0.06 & 3.36 & 0.47 \\
3 & 10 & 0.25 & 4.23 & 1.27 \\
4 & 10 & 0.14 & 2.25 & 1.08 \\
Strombine & & & & \\
0 & 8 & 0.22 & 1.10 & 0.66 \\
1 & 11 & 0.13 & 3.74 & 0.93 \\
2 & 12 & 0.09 & 4.13 & 0.91 \\
3 & 10 & 0.30 & 6.35 & 1.53 \\
4 & 10 & 0.10 & 3.95 & 0.88 \\
& & & & \\
\hline
\end{tabular}

\section{Recovery}

Specimens of Arenicola marina were collected after $4 \mathrm{~h}$ of emersion and were incubated in normoxic seawater in order to investigate recovery from tidal exposure. The median sulfide concentration in the coelomic
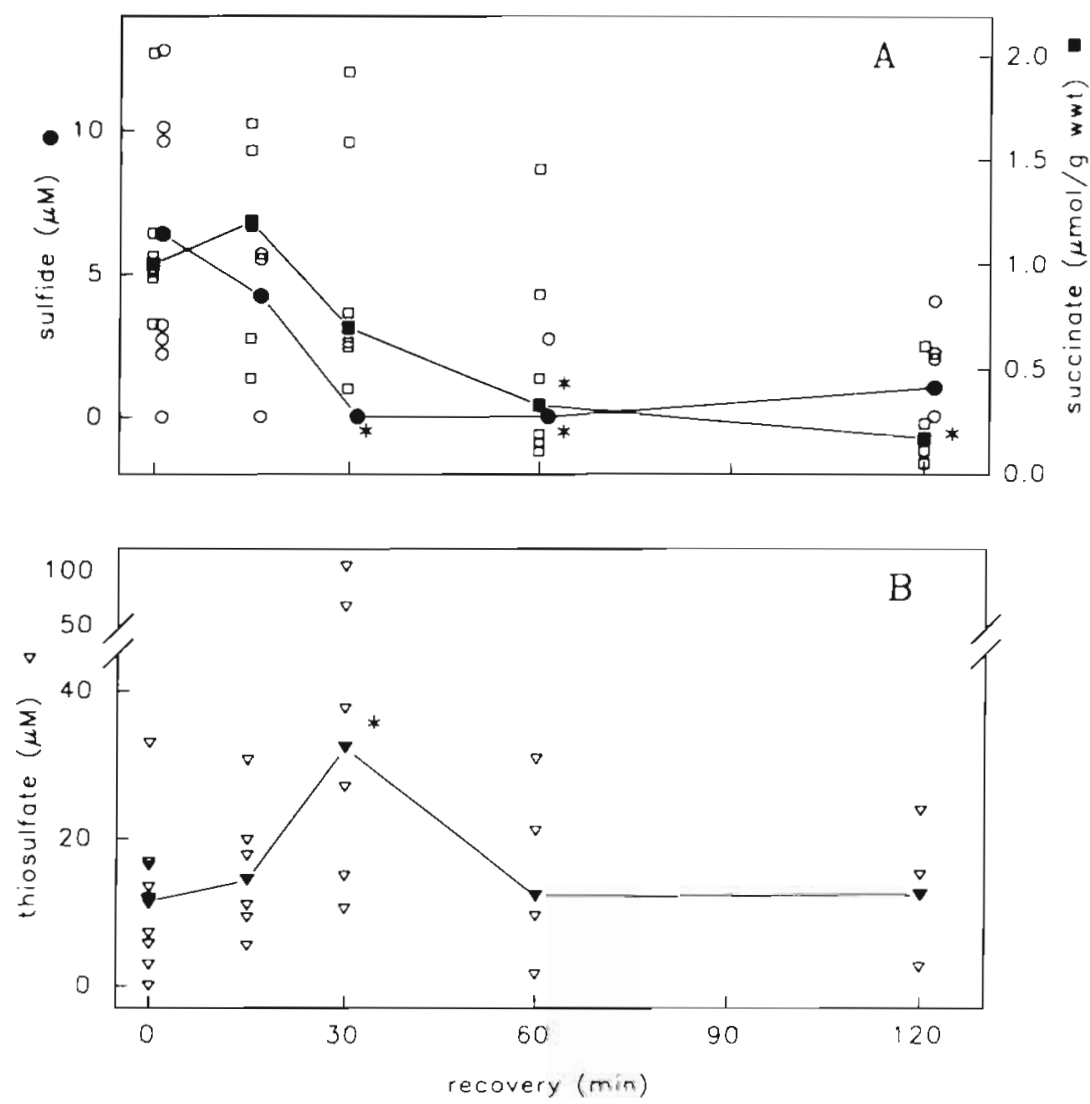

Fig. 4. Arenicola marina. (A) Sulfide in the coelomic fluid $(\mu \mathrm{M} ; \circ)$ and succinate in the body wall tissue ( $\mu$ mol $\mathrm{g}^{-1}$ wet wit; $\left.\square, \boldsymbol{\square}\right)$ and $(B)$ thiosulfate in the coelomic fluid $(\mu \mathrm{M} ; \nabla, \nabla)$ of lugworms collected in October. Lugworms were collected after $4 \mathrm{~h}$ of tidal emersion $(t=0 \mathrm{~min})$ and were allowed to recover in normoxic seawater. Open symbols represent data from individual lugworms; closed symbols are median concentrations. (*) Median concentration is significantly different from the median at $t=0 \mathrm{~min}$. The data for $t=0$ min are identical with $t=4 \mathrm{~h}$ (October) in Fig. 3. For clarity, sulfide data in (A) are shifted to the right. The number of lugworms at $t=0,15,30,60$ and $120 \mathrm{~min}$ of recovery was (with the number of lug. worms containing no sulfide in parentheses): $9(2), 5(2), 6(6), 5(4)$ and $6(3)$. Thiosulfate and succinate were found in all Iugworms $(n=5$ or 6$)$ 
fluid began to decrease from $6.4 \mu \mathrm{M}$ (see above) to $4.2 \mu \mathrm{M}$ after $15 \mathrm{~min}$ of recovery (Fig. 4A). Sulfide was completely removed from the coelomic fluid after $30 \mathrm{~min}$ of recovery. Succinate concentrations were still high after $15 \mathrm{~min}$ of recovery (median $=1.21 \mu_{\mathrm{mol} \mathrm{g}}^{-1}$ wet $w \mathrm{t})$, began to decrease after $30 \mathrm{~min}\left(0.7 \mu \mathrm{mol} \mathrm{g}^{-1}\right.$ wet wt) and reached control values after 60 and $120 \mathrm{~min}$ of recovery (medians $=0.33$ and $0.17 \mu \mathrm{mol} \mathrm{g}^{-1}$ wet $w t$, respectively) (Fig. $4 \mathrm{~A}$ ). In contrast, the median thiosulfate concentration in the coelomic fluid of $A$. marina showed a sudden significant increase from 14.4 to $32.4 \mu \mathrm{M}$ after $30 \mathrm{~min}$ of recovery with concentrations ranging from 10.6 to $103.5 \mu \mathrm{M}$ (Fig, 4B). After $60 \mathrm{~min}$ of recovery, the median thiosulfate concentration had returned to the control value of $12.3 \mu \mathrm{M}$, concentrations ranging from 1.6 to $30.9 \mu \mathrm{M}$.

\section{DISCUSSION}

\section{Environmental sulfide concentrations}

Sulfide was measured in the pore water of the sediment in the vicinity of lugworm burrows in order to see whether sulfide concentrations vary during tidal exposure. Like many other marine sediments (Ott \& Novak 1989) the area exhibited a pronounced heterogeneity (Fig. 1). Maximal sulfide concentrations were comparable to earlier investigations $[250 \mu \mathrm{M}$ in this study as compared to $340 \mu \mathrm{M}$ in Völkel \& Grieshaber (1992) with both values obtained from July measurements]. Sulfide concentrations decreased with depth (Fig. 1): the maximal concentration was only $44 \mu \mathrm{M}$ at a depth of $30 \mathrm{~cm}$, which may be due to a decreasing rate of sulfate reduction parallel to a decreasing sulfate gradient in the sediment (Jørgensen 1977).

Although in some cases pore water sulfide concentrations increased during $4 \mathrm{~h}$ of tidal emersion, variations between different sampling sites were high and no significant changes of sulfide concentrations could be observed.

Sulfide concentrations in the water of lugworm burrows were generally lower than pore water concentrations although sulfide was detected in $42 \%$ of the analyzed burrows. Most of them did not contain any sulfide just after the water had receded. During $4 \mathrm{~h}$ of tidal emersion the percentage of burrows containing sulfide doubled whereas median sulfide concentrations in the burrow rose slightly but not significantly. A significant increase to $14.5 \mu \mathrm{M}$ was only observed after $5 \mathrm{~h}$ of emersion in October (Fig. 2). In July, however, sulfide concentrations up to $30 \mu \mathrm{M}$ could be measured in single burrows over the whole period of emersion. These sporadic high values may be due to sediment heterogeneity as mentioned above. On the other hand, sulfide concentrations in burrow water is frequently higher in summer than in winter and spring (Arp et al. 1989).

Arp et al. (1992) found sulfide in 50 to $70 \%$ of Urechis caupo burrows with maximal concentrations of 25 to $65 \mu \mathrm{M}$ (samples from 2 different sites, respectively). In their study samples were taken about $2 \mathrm{~h}$ after emersion and unfortunately these authors give no sulfide concentrations at the beginning of low tide. Waslenchuk et al (1983) analyzed burrows of Callianassa spp. which were covered with water over the whole sampling period. They found sulfide concentrations of 2.0 to $26 \mu \mathrm{M}$ in the burrow water as opposed to less than $0.1 \mu \mathrm{M}$ in the overlying water and 100 to $1000 \mu \mathrm{M}$ in the pore water. Although the shrimps vigorously flush their burrows, irrigation is not continuous and therefore seems to be insufficient to maintain sulfide-free burrows (Waslenchuk et al. 1983). Arenicola marina also exhibits an intermittent irrigation pattern (Davey et al. 1990). It is, therefore, possible that $A$. marina is occasionally exposed to short-term increases of sulfide concentrations in its burrows during high tide. This may explain why sulfide was already found in some burrows at the beginning of low tide (Fig, 2).

\section{Sulfur compounds in freshly caught Arenicola marina}

Sulfide concentrations in the coelomic fluid of Arenicola marina were measured every hour during $4 \mathrm{~h}$ of tidal emersion in order to see how much sulfide is taken up by the worms under habitat conditions. When the flat fell dry, the percentage of lugworms containing sulfide increased with exposure time, along with both the median and the maximal sulfide concentrations in the coelomic fluid. Due to the high variability between lugworms, the increase of median sulfide concentration was only significant after 2 and $3 \mathrm{~h}$ in July and after $4 \mathrm{~h}$ in October (Fig. 3A). Immediately after the water had receded only low sulfide concentrations $(<10 \mu \mathrm{M})$ were found in a few lugworms whereas no sulfide could be measured in about $70 \%$ of the lugworms. These data indicate that either no sulfide was present in the burrow water of these lugworms or that some sulfide was present but that entering sulfide could be oxidized due to a sufficiently high oxygen supply during high tide. In earlier investigations (Völkel \& Grieshaber 1994) we observed that under normoxic conditions $A$. manina is able to prevent an increase of sulfide in the coelomic fluid up to an external sulfide concentration of at least $330 \mu \mathrm{M}$, since sulfide entering the body is rapidly oxidized to thiosulfate. Fig. 3B shows that thiosulfate concentrations up to $40 \mu \mathrm{M}$ are present immediately after the water has receded, indicating that some sulfide must have been present in the body of these lugworms and that this sul- 
fide had been oxidized during high tide. Oeschger \& Vetter (1992) measured sulfide and thiosulfate in the hemolymph of freshly caught priapulid Halicryptus spinulosus living in anoxic sediments of the Western Baltic. In their study sulfide concentrations of 86 to $445 \mu \mathrm{M}$ were measured whereas thiosulfate amounted to 21 to $84 \mu \mathrm{M}$. These high internal sulfide levels may be a consequence of limited oxygen conditions together with pore water sulfide concentrations up to $665 \mu \mathrm{M}$. (Oeschger \& Vetter 1992).

In the coelomic fluid of Arenicola marina collected in July, sulfide concentrations rose significantly to about $35 \mu \mathrm{M}$ after $3 \mathrm{~h}$ of emersion and maximal concentrations were even higher (Fig. 3A). In the lugworm burrows sulfide levels were 20 to $30 \mu \mathrm{M}$ at most (Fig. 2). Sulfide concentrations within lugworms, therefore, can be higher than burrow water concentrations. In laboratory experiments sulfide concentrations in the coelomic fluid were $60 \mu \mathrm{M}$ after $8 \mathrm{~h}$ of hypoxic ( $\mathrm{P}_{\mathrm{O}_{2}}=3$ torr) sediment-free incubation at an external sulfide level of $200 \mu \mathrm{M}$ (Völkel \& Grieshaber 1992). Internal sulfide concentrations reported by Völkel \& Grieshaber were comparable to those which were found in the present study. Under laboratory conditions, however, sulfide concentrations in the coelomic fluid were much lower than external. sulfide concentrations. This was due to a $\mathrm{pH}$-dependent limited influx of sulfide into the body of A. marina (Groenendaal 1981, Völkel \& Grieshaber 1992). Under field conditions sulfide may have entered the lugworm by it feeding on sulfide-rich sediment.

The increase of sulfide within lugworms during low tide indicates that sulfide oxidation was not possible due to the lack of oxygen. In an earlier investigation (Völkel \& Grieshaber 1994) sulfide oxidation proved to be oxygen dependent. Thiosulfate concentrations in the coelomic fluid of Arenicola marina were only $2 \mu \mathrm{M}$ after hypoxic sulfide incubations at a $\mathrm{P}_{\mathrm{O}_{2}}$ of 0.7 torr as opposed to $4.2 \mathrm{mM}$ at a $\mathrm{P}_{\mathrm{O}_{2}}$ of 130 torr (8 h, external sulfide $550 \mu \mathrm{M}$; Völkel \& Grieshaber 1994). Although thiosulfate concentrations were slightly higher in July than in October, no changes of thiosulfate concentrations were observed during tidal exposure (Fig. 3b). Völkel (1992) demonstrated that during hypoxia thiosulfate disappears very slowly from the coelomic fluid of A. marina, which may explain the constant thiosulfate concentrations during tidal exposure.

\section{Anaerobic metabolites in freshly caught Arenicola marina}

During tidal exposure the stagnant water conditions in lugworm burrows can cause anoxia as well as enhanced sulfide load. Both factors prevent aerobiosis, leading to anaerobic metabolism. In an earlier study we demonstrated the accumulation of the anaerobic metabolites succinate, alanopine and strombine in the body wall tissue of Arenicola marina during sulfide incubations under hypoxic conditions (Völkel \& Grieshaber 1992,1994). In the present investigation tissue concentrations of anaerobic metabolites were measured in order to follow the onset of anaerobic metabolism during tidal exposure. Succinate in the body wall tissue of Arenicola marina collected in October increased significantly from $0.21 \mathrm{\mu mol} \mathrm{g}^{-1}$ wet wt to $1.01 \mu \mathrm{mol} \mathrm{g} \mathrm{g}^{-1}$ wet wt after $4 \mathrm{~h}$ of emersion (Fig. 3C). These data show that anaerobiosis commenced at least after $2 \mathrm{~h}$ of tidal exposure. In laboratory experiments succinate amounted to about $1 \mu \mathrm{mol} \mathrm{g}{ }^{-1}$ wet wt after $8 \mathrm{~h}$ of hypoxia ( $\mathrm{P}_{\mathrm{O}_{2}} 1$ to 2 torr) and to about $2 \mu \mathrm{mol} \mathrm{g} \mathrm{g}^{-1}$ wet wt after $8 \mathrm{~h}$ of hypoxic sulfide incubations (external sulfide 200 and $1000 \mu \mathrm{M}$, respectively) (Volkel \& Grieshaber 1992). The above data correspond well to succinate levels in the body wall tissue of freshly caught $A$. marina found in the present study.

Unfortunately, it is impossible to distinguish between environmental and sulfide-dependent anaerobiosis since we do not know the oxygen and sulfide concentrations in the burrow water of the individual lugworms. Fig. 5 shows that most of the lugworms which contain sulfide exhibit high succinate levels ( 0.9 to $1.2 \mu \mathrm{mol} \mathrm{g}{ }^{-1}$ wet $\mathrm{wt}$ ), as aerobiosis cannot be maintained due to inhibition of the cytochrome c oxidase. In contrast, less succinate $\left(0\right.$ to $0.6 \mu \mathrm{mol} \mathrm{g}^{-1}$ wet wt) was found in most lugworms without sulfide. In many other specimens, however, succinate levels were high although no sulfide could be found in their coelomic fluid. In that case, anaerobiosis was probably caused by anoxia and not by sulfide.

Schottler et al. (1984b) measured $0.14 \mu_{\mathrm{mol} \mathrm{g}}{ }^{-1}$ wet wt succinate in the tissue of Arenicola marina at the beginning of low tide, increasing to 0.25 after $2 \mathrm{~h}$ and to $0.28 \mu \mathrm{mol} \mathrm{g}^{-1}$ wet wt after $4 \mathrm{~h}$ of emersion. In the above study the authors give no sulfide concentrations in the environment or in the lugworms. Possibly, the lower succinate level, as compared to the present study, was a consequence of a lower sulfide stress. Schöttler (1989) demonstrated that the extent of anaerobic metabolism also depends on the season, the locality of the intertidal burrow and the development of gametes. Correspondingly, summer specimens of $A$. marina accumulated significantly more succinate during normoxic sulfide incubations than winter specimens (Völkel \& Grieshaber 1994). In the present study, however, no differences of succinate levels between lugworms collected in July and those collected in October were observed (Fig. 3C) although sulfide exposure was significantly higher in July (Fig. 3A). Sulfide entering the body of $A$. marina may quickly reach a critical level ${ }_{i}$ the cytochrome coxidase is blocked, also 


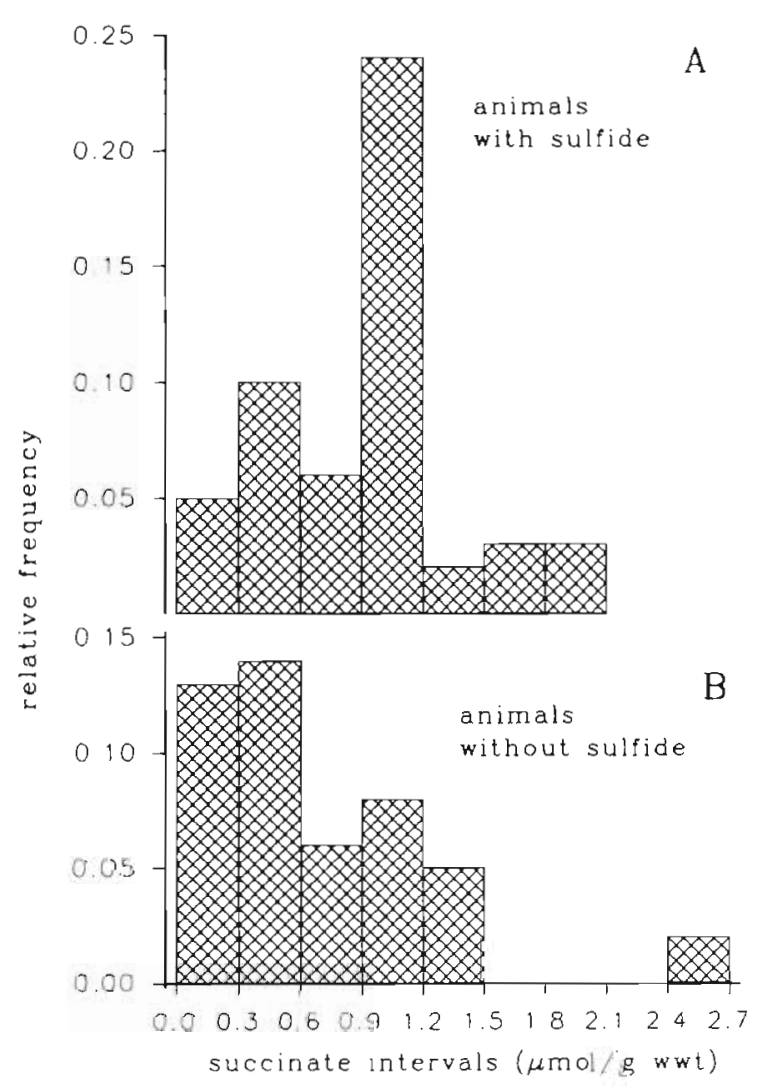

Fig. 5. Arenicola marina. Relative frequency of lugworms plotted against intervals of succinate in the body wall tissue ( $\mu \mathrm{mol} \mathrm{g}^{-1}$ wet wt). Data are obtained from all lugworms (July and October) during the whole period of tidal emersion (see Fig. 3A) for (A) specimens with sulfide and (B) specimens without measurable sulfide in the coelomic fluid

leading to maximal anaerobiosis which does not depend on the sulfide concentration. During hypoxic sulfide incubations there was no difference between succinate accumulation at external sulfide concentrations of 200 or $1000 \mu \mathrm{M}$ (Völkel \& Grieshaber 1992).

In addition to succinate, we measured opine levels in the body wall tissue of lugworms collected in July. Alanopine did not change significantly although maximal concentrations tended to increase in the first $3 \mathrm{~h}$ of emersion (Table 1 ). Strombine concentrations increased significantly during the first $3 \mathrm{~h}$ of tidal exposure. Alanopine and strombine both are glycolytic end products, with alanopine being accumulated preferentially during functional and strombine during environmental anaerobiosis (Siegmund et al. 1985, see also Grieshaber et al. 1992). Strombine therefore accumulates predominantely in Arenicola marina during tidal hypoxia with maximal concentrations being higher than maximal alanopine concentrations. Völkel \& Grieshaber (1992) demonstrated that much more strombine is accumulated during $8 \mathrm{~h}$ of hypoxia, hypoxia plus sulfide, and normoxia plus sulfide as compared to alanopine. Tissue levels of alanopine were about 1 to $1.5 \mu \mathrm{mol} \mathrm{g}{ }^{-1}$ wet wt whereas strombine amounted to $4 \mu \mathrm{mol} \mathrm{g}^{-1}$ wet wt (Völkel \& Grieshaber 1992).

\section{Recovery}

During tidal exposure, sulfide and succinate accumulate in the body of Arenicola marina whereas thiosulfate concentrations remain constant (Fig. 3). As soon as the tide comes back in, the lugworm can irrigate its burrow again. Sulfide which has accumulated in the burrow water is flushed out and the presence of oxygen enables the worm to oxidize sulfide which may have entered its body. When internal sulfide has disappeared, the cytochrome c oxidase is no longer inhibited and $A$. marina is able to switch back to aerobic metabolism. In the present study we mimicked the incoming tide by placing the lugworms into aerated seawater tanks after $4 \mathrm{~h}$ of tidal exposure in the sediment. Sulfide concentrations in the coelomic fluid began to decrease immediately and reached control levels after $30 \mathrm{~min}$ of recovery (Fig. 4A). Two mechanisms may be involved in the disappearance of sulfide: the diffusion into the external medium and the oxidation of sulfide to thiosulfate. The diffusion of sulfide may certainly play a role because biological membranes are permeable to sulfide (Beerman 1924, Julian \& Arp 1992, Völkel \& Grieshaber 1992). On the other hand, Fig. $4 \mathrm{~B}$ shows that thiosulfate in the coelomic fluid of A. marina increases significantly after 30 min of recovery. A rough estimation reveals that sulfide disappears from the coelomic fluid with a rate of $0.12 \mathrm{nmol}$ $\mathrm{min}^{-1} \mathrm{~g}^{-1}$ whereas thiosulfate production is $0.26 \mathrm{nmol}$ $\mathrm{min}^{-1} \mathrm{~g}^{-1}$ (assuming a lugworm weight of about $10 \mathrm{~g}$ and a relative amount of coelomic fluid of $40 \%$ ). One mole of produced thiosulfate is equivalent to 2 moles of oxidized sulfide. Therefore, thiosulfate production during the first $30 \mathrm{~min}$ of recovery must be the consequence of the oxidation of $0.52 \mathrm{nmol} \mathrm{min}{ }^{-1} \mathrm{~g}^{-1}$ sulfide which is 4 -fold higher than the measured rate of sulfide removal. On the other hand, sulfide concentrations in the body wall tissue are much higher as compared to the coelomic fluid. For example, after $7 \mathrm{~h}$ of hypoxic incubations at an external sulfide concentration of $25 \mu \mathrm{M}$, sulfide concentrations increased by about 2 to $3 \mu \mathrm{M}$ in the coelomic fluid and about $30 \mu \mathrm{M}$ in the body wall tissue of $A$. marina (K. Hauschild unpubl. results). Unfortunately, it was not possible to determine tissue sulfide levels because we were not able to determine the fresh weight of the tissue under field conditions. If we assume a similar increase of sulfide in the body wall musculature as seen under experimental conditions, the total removal of sulfide would require a rate

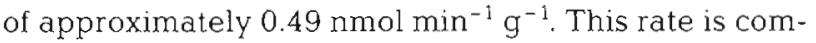


parable to the rate of the actual thiosulfate production. Although the mechanisms of sulfide removal during recovery from sulfide exposure remain to be investigated in detail, it can be assumed that the oxidation of sulfide to thiosulfate plays a major role in this process. After $60 \mathrm{~min}$ of recovery thiosulfate in the coelomic fluid reached the same level as during low tide (Fig. 4B). Very little is presently known about degradation or excretion of thiosulfate. It may be further oxidized to sulfate or it may be excreted via the nephridia. Thiosulfate is not completely removed from the coelomic fluid during $120 \mathrm{~min}$ of recovery. Possibly, any thiosulfate oxidizing or transporting system is only activated by thiosulfate concentrations above a critical threshold.

Parallel to the disappearance of sulfide, the succinate level in the body wall tissue decreases during recovery. Although sulfide had reached control levels after 30 min of recovery, loss of succinate appeared to be slower (Fig. 4A). Pörtner et al. (1979) showed that succinate began to decrease immediately after the onset of aerobic conditions and reached control levels after 1 to $2 \mathrm{~h}$ of recovery from anaerobiosis. From the change of energy status and the immediate cessation of fumarate reduction they concluded that Arenicola marina is able to utilize oxygen as soon as it is available. In the presence of sulfide, however, a rapid onset of aerobiosis is not possible. Fig. 4A shows that considerably high sulfide concentrations are still present after $15 \mathrm{~min}$ of recovery. Correspondingly, the succinate level is still high at this moment. Only when sulfide has disappeared can $A$. marina switch back to an aerobic metabolism, as indicated by decreasing succinate concentrations after $30 \mathrm{~min}$ of recovery (Fig. 4A).

During recovery, thiosulfate concentration in the coelomic fluid of Arenicola marina was maximal after 30 min when sulfide had reached control levels and succinate has decreased (Fig. 4B). Thiosulfate production, however, started earlier when sulfide and succinate levels may still have been high. In an earlier investigation (Völkel \& Grieshaber 1994) we observed an accumulation of thiosulfate in the coelomic fluid of A. marina during normoxic sulfide incubations $\left(\mathrm{P}_{\mathrm{O}_{2}}=130\right.$ torr, external sulfide $1 \mathrm{mM}$ ). In the latter study sulfide was oxidized although internal levels of sulfide and succinate were high.These data indicate that sulfide oxidation in the presence of oxygen is possible even when aerobic metabolism is inhibited by sulfide. Previously we demonstrated that mitochondrial sulfide oxidation in $A$. marina is sulfide insensitive and assumed the existence of an alternative terminal oxidase (Völkel \& Grieshaber 1994). This sulfide detoxification system enables the worm to remove sulfide quickly from its body and to rapidly return to an aerobic metabolism.

\section{Conclusions}

The lugworm Arenicola marina can be exposed to considerably high sulfide concentrations during tidal exposure. Sulfide concentrations can also increase sporadically in some burrows during high tide. Under habitat conditions the lugworm seems to exhibit the same mechanisms of sulfide tolerance as under experimental conditions. In the presence of oxygen, sulfide entering the body of $A$. marina is oxidized to thiosulfate. During high tide, therefore, an increase of sulfide in the body is prevented. Under hypoxic conditions during tidal exposure sulfide cannot be oxidized and sulfide concentrations in the coelomic fluid increase. The accumulation of sulfide together with hypoxia prevent aerobic metabolism and the lugworm switches to anaerobiosis. The lower coelomic $\mathrm{pH}$ as compared to burrow water (B. Giebels unpubl. results) may keep internal sulfide concentrations in some lugworms below the external level. However, coelomic sulfide concentrations increase above external concentrations in many other specimens. When the tide returns and the burrows are immersed sulfide in the body of $A$. marina is rapidly oxidized, which enables the worm to return to aerobic metabolism. After $1 \mathrm{~h}$ of recovery in normoxic seawater sulfide, succinate and thiosulfate have reached the same level as at the beginning of low tide, indicating that 1 high tide is more than sufficient for recovery from sulfide stress during tidal exposure.

Acknowledgements. We thank Silke Jakob for skilful technical assistance. Thanks are also due to our Düsseldorfer collegues for their help in collecting the lugworms. K.H. is a fellow of the Konrad-Adenauer Foundation. Financial support from the Bundesminister für Forschung und Technologie (DYSMON 03F0123B) is also acknowledged

\section{LITERATURE CITED}

Aller RC (1980) Quantifying solute distributions in the bioturbated zone of marine sediments by defining an average micro-environment. Geochim Cosmochim Acta 44 $1955-1965$

Arp AJ, Hansen BM, Julian D (1989) Seasonal sulfide concentrations of the burrow habitat of Urechis caupo: hematin mediated sulfide tolerance in situ. Am Zool 29:69A

Arp AJ, Hansen BM, Julian D (1992) Burrow environment and coelomic fluid characteristics of the echiuran worm Urechis caupo from populations at three sites in northern California. Mar Biol 113:613-623

Bagarinao T (1992) Sulfide as an environmental factor and toxicant: tolerance and adaptations in aquatic organisms. Aquat Toxicol 24:21-62

Beerman H (1924) Some physiological actions of hydrogen sulfide. J exp Zool 41:33-43

Beis J, Newsholm EA (1975) The contents of adenine nucleotides, phosphagens and some glycolytic intermediates in resting muscles from vertebrates and invertebrates. Biochem J 152:23-32 
Beutler HO (1985) Succinat. In: Bergmeyer HU (ed) Methods of enzymatic analysis. Verlag Chemie, Weinheim, p 25-33

Beyer H (1988) U-Test von Wilcoxon, Mann und Whitney ein verteilungsunabhängiges statistisches Verfahren für den Vergleich zweier unabhängiger Stichproben. Z ärztl Fortbild 82:871-873

Brafield AE (1964) The oxygen content of interstitial water in sandy shores. J Anim Ecol 33:97-116

Cline JD, Richards FA (1969) Oxygenation of hydrogen sulfide in seawater at constant salinity, temperature and $\mathrm{pH}$ Environ Sci Technol 3:838-843

Davey JT, Watson PG, Bruce RH, Frickers PE (1990) An instrument for the monitoring and collection of the vented burrow fluids of benthic infauna in sediment microcosms and its application to the polychaetes Hediste diversicolor and Arenicola marina. J exp mar Biol Ecol 139:135-149

De Wit $R$, Jonkers HM, Van den Ende F, Van Gemerden $H$ (1989) In situ fluctuations of oxygen and sulphide in marine microbial sediment ecosystems. Neth $\mathrm{J}$ Sea Res 23:271-281

Fenchel TM, Riedl RJ (1970) The sulfide system: a new biotic community underneath the oxidized layer of marine sand bottoms. Mar Biol 7:255-268

Gilboa-Garber N (1971) Direct spectrophotometric determination of inorganic sulfide in biological materials and in other complex mixtures. Analyt Biochem 43:129-133

Grieshaber MK, Hardewig I, Kreutzer U, Schneider A, Völkel $S$ (1992) Hypoxia and sulfide tolerance in some marine invertebrates. Verh dtsch Zool Ges 85:55-76

Groenendaal M (1979) On sulphide and the distribution of Arenicola marina in a tidal mud flat in the Dutch wadden sea. Neth J Sea Res 13:562-570

Groenendaal M (1980) Tolerance of the lugworm (Arenicola marina) to sulphide. Neth J Sea Res 14:200-207

Groenendaal M (1981) The adaptation of Arenicola marina to sulfide solutions. Neth J Sea Res 15;65-77

Jones JD (1955) Observations on the respiratory physiology and on the haemoglobin of the polychaete genus Nephthys, with special reference to $N$ hombergii. J exp Biol $32: 110-125$

Jorgensen BB (1977) The sulfur cycle of a coastal marine sediment (Limfjorden, Denmark). Limnol Oceanogr 22: $814-832$

Jørgensen BB, Fenchel T (1974) The sulfur cycle of a marine sediment model system. Mar Biol 24:189-201

Julian D, Arp AJ (1992) Sulfide permeability in the marine invertebrate Urechis caupo. J comp Physiol 162B:59-67

Kröger A, Schröder J, Paulsen J, Beilman A (1988) Acetate oxidation with sulphur and sulphate as terminal electron acceptors. In: Cole JA, Ferguson SJ (eds) The nitrogen and sulphur cycles. Cambridge University Press, Cambridge, p $133-145$

Krüger F (1971) Bau und Leben des Wattwurmes Arenicola marina. Helgoländer wiss Meeresunters 22:149-200

Millero FJ (1986) The thermodynamics and kinetics of the hydrogen sulfide system in natural waters. Mar Chem $18: 121-147$

National Research Council (1979) Hydrogen sulfide. University Park Press, Baltimore, p 1-183

Nedwell DB. Floodgate GD (1972) Temperature-induced changes in the formation of sulphide in a marine sediment. Mar Biol 14:18-24

Oeschger R, Vetter RD (1992) Sulfide detoxification and tolerance in Halicryptus spinulosus (Priapulida): a multiple strategy. Mar Ecol Prog Ser 86:167-179
Ott JA, Novak R (1989) Living at an interface: meiofauna at the oxygen/sulfide boundary of marine sediments. In: Ryland JS, Tyler PA (eds) Reproduction, genetics and distributions of marine organisms. 23rd Eur Mar Biol Symp. Olsen \& Olsen, Fredensborg, p 415-422

Pionetti J-M, Toulmond A (1980) Tide-related changes of volatile fatty acids in the blood of the lugworm, Arenicola marina (L.). Can J Zool 58:1723-1727

Pörtner HO, Surholt B, Grieshaber M (1979) Recovery from anaerobiosis of the lugworm Arenicola marina L : changes of metabolite concentrations in the body-wall musculature. J comp Physiol 133:227-231

Schöttler U (1989) Anaerobic metabolism in the lugworm Arenicola marina during low tide: the influence of developing reproductive cells. Comp Biochem Physiol 92A $1-7$

Schöttler U, Wienhausen G, Westermann J (1984a) Anaerobic metabolism in the lugworm Arenicola marina L.: the transition from aerobic to anaerobic metabolism. Comp Biochem Physiol 79B:93-103

Schöttler U, Surholt B, Zebe E (1984b) Anaerobic metabolism in Arenicola marina and Nereis diversicolor during low tide. Mar Biol 81:69-73

Siegmund B, Grieshaber MK, Reitze M, Zebe E (1985) Alanopine and strombine are end products of anaerobic glycolysis in the lugworm Arenicola marina L. Comp Biochem Physiol 82B:337-345

Toulmond A (1973) Tide-related changes of blood respiratory variables in the lugworm, Arenicola marina (L.). Resp Physiol 19:130-144

Toulmond A (1987) Adaptations to extreme hypoxia in water breathers. Comp Physiol environ Adapt 2:123-136

Toulmond $\mathrm{A}$, Tchernigovtzeff $\mathrm{C}$ (1984) Ventilation and respiratory gas exchange of the lugworm Arenicola marina $\mathrm{L}$ as functions of ambient $\mathrm{P}_{\mathrm{O}_{2}}(20-700$ torr). Resp Physiol $57: 349-363$

Vetter RD, Matrai PA, Javor B, O'Brien J (1989) Reduced sulfur compounds in the marine environment: analysis by HPLC. In: Saltzman E, Cooper W (eds) Biogenic sulfur in the environment. American Chemical Society, Symposia Series 393, p 243-261

Vetter RD, Powell MA, Somero GN (1991) Metazoan adaptation to hydrogen sulfide. In: Bryant $C$ (ed) Life without oxygen. Chapman and Hall, London

Vismann B (1991) Sulfide tolerance: physiological mechanisms and ecophysiological implications. Ophelia 34:1-27

Völkel S (1992) Ökophysiologische Untersuchungen über die Sulfidtoleranz des Wattwurmes Arenicola marina L. PhD thesis, Shaker Verlag, Aachen

Völkel S, Grieshaber MK (1992) Mechanisms of sulfide tolerance in the peanut worm Sipunculus nudus (Sipunculida) and in the lugworm Arenicola marina (Polychaeta). J comp Physiol 162B:469-477

Völkel S, Grieshaber MK (1994) Oxygen-dependent sulfide detoxification in the lugworm Arenicola marina. Mar Biol 118:137-147

Waslenchuk DG, Matson EA, Dobbs FC, Tramontano JM (1983) Geochemistry of burrow waters vented by a bioturbating shrimp in bermudian sediments. Mar Biol 72: $219-225$

Watling L (1991) The sedimentary milieu and its consequences for resident organisms. Am Zool 31:789-796

Wollenberger AO, Ristan O, Schoffa G (1960) Eine einfache Technik der extrem schnellen Abkühlung grösserer Gewebestücke. Pflügers Arch 270:399-412 